\title{
Conference of Eastern College Libraries, I940
}

Robert Bingham Downs is director of libraries at New York University.

$\mathrm{T}$ HE ATTENDANCE at the twenty-eighth annual Conference of Eastern College Librarians, meeting at Columbia University on November 23, was the largest on record. Approximately 500 college and university librarians were present, chiefly from the Middle Atlantic and New England states.

The morning session was devoted to subjects primarily of interest to college librarians: annual book lists, setting up standards for college library functions, rare books in the college, and college library building plans.

In his paper on "Standards for Surveying Library Functions in the College Program" Peyton Hurt, librarian of Williams College, indicated the chief problem in evaluating a library is to know what to survey and how much weight to give each factor in measuring the library's efficiency. Some essential factors are intangible and difficult or impossible to measure. Furthermore, every library should be given individual appraisal on the basis of the aims of the college which it serves. The first step in the surveying process is to define the place of the college library in the college program. This includes such points as the extent and nature of the book collection, the library building's suitability for its functions, ability of the staff, effectiveness of the library organization, and the attitude of the president, faculty, and students towards the library. Dr. Hurt emphasized that certain objective principles should be established by which standards for library functions could be set up. These principles would comprise the nature of the college program, the financial limitations of the college, the policies of the president and faculty, teaching methods employed, amount of independent study and reading done, the extent and nature of faculty research, the influence of the library on the college program, and activities of the library outside its required functions.

Many college librarians have expressed a need for up-to-date standard book-buying lists and have urged the publication of such guides, perhaps on an annual basis. Charles B. Shaw, librarian of Swarthmore College and editor of $A$ List of Books for College Libraries, presented some of the problems connected with more frequent supplements. To make up arrears, Mr. Shaw suggested issuing a three-year volume for I939-I94I. There would then be two possibilities: a series of annual volumes, beginning with 1942 , or a quarterly list, the latter as a separate pamphlet or as a section of College and Research Libraries. Since specialized book reviews are not ordinarily available for a year or more after a book has been published, either timeliness or authoritativeness must 
be sacrificed in the preparation of these lists. A possible combination would be promptly published quarterly lists, followed by more carefully selected five-year supplements, the latter dropping titles which had proven of ephemeral value. The vote of those attending the conference favored authoritative rather than timely lists.

\section{Rare Books in a College Library}

The place of rare books in a college library has been widely debated. Lucy E. Osborne, custodian of the Chapin Library, Williams College, told of the extensive uses made of that great collection of rare books. The uses are of three types: exhibits, class work, and individual reference and research. Seven exhibitions are put on annually, including those of a commemorative nature, materials to illustrate courses, and subjects of general interest. As for class use, some instructors, particularly in fine arts and English, hold regular planned meetings in the Chapin Library to bring the students in direct contact with first editions, incunabula, and other valuable materials. Miss Osborne strongly recommended that any college with rare books, even if it possessed only a few examples, make full use of them for exhibition and instructional purposes.

The new library building at Skidmore College was described by its architect, Louis Jallade. Due to limited funds, the planners of the building had to decide whether to erect a small complete structure, which would soon be outgrown, or to construct one section of a larger, more adequate building capable of considerable expansion and flexibility. The second plan was adopted. The stack only was built, a portion of it cut off for temporary use for reading rooms, offices, and other purposes. Future additions to the building can be made with no fundamental alterations in the present structure. A modern feature is fluorescent lighting, adopted for the entire building at an installation cost more than double that of incandescent lighting, but with an annual saving of one half in power cost.

\section{Library Cooperation and Planning}

At the beginning of the afternoon session Ernest J. Reece, of the Columbia School of Library Service, read by title his yearly report on "College and University Library News," to be published shortly in the Library Journal. The afternoon's discussion was given over wholly to problems of library cooperation and planning. Conyers Read, executive secretary of the American Historical Association and chairman of the Bibliograpical Planning Committee for the Philadelphia Metropolitan Area, reviewed that committee's activities and future aims. Studies have been made of the community and its book needs, not merely in relation to scholars, teachers, and students, but professional workers, groups with low cultural backgrounds, suburbanites, and others. The Philadelphia Union Catalog, covering 150 libraries, is regarded as only a first step. It is being followed by surveys of resources in the numerous educational, public, and special libraries of the city to make these facilities more widely useful. Other problems of cooperation are likewise receiving attention, among them cooperative cataloging, development of special libraries, building up a bibliographical center, and a regional storehouse for little-used books.

Julian P. Boyd, librarian of Princeton University, presented a proposal, which had grown out of a recent meeting of 
eastern university librarians, for organizing a special division in the Library of Congress to act as a clearing house and advisory agency for all cooperative library undertakings. Such a department might assist in such matters as regional catalogs, surveys of resources, divisions of collecting interests, and cooperative storehouses.

In reply, Archibald MacLeish, Librarian of Congress, expressed the willingness of the Library of Congress to assist in this program, if it is requested by the librarians of the country. Mr. MacLeish stressed the fact, however, that the $\mathrm{Li}$ brary of Congress must have added support for any new ventures, and that the library is decidedly short on top administrative officers. On motion of Harry Miller Lydenberg, the conference voted to approve Mr. Boyd's proposal and to support it in any practical fashion.

\section{Colorado University's Divisional Reading Room Plan}

(Continued from page rog)

ing in one divisional area. Thus far, no one on the campus has complained that too much service of a high quality is given.

It is true that full professional service is not provided fourteen hours a day, but we take the position that eight hours of highly specialized service is better than fourteen hours of average service. We are discovering that the graduate student assistants who have worked several years in the library can handle in a reasonably competent manner the elementary reference questions in their subject fields.

Fifth, what about the problem of discipline in the reading rooms which are broken into small units? Perhaps college students in this area are more mature than is the case elsewhere, but we doubt it. From the first day the new building opened, students have acted as we had assumed they would. No one has to take books to get his assignments done; therefore, few books are lost. The reading rooms are quiet. In other words, provide a scholarly atmosphere and students will act accordingly.
Sixth, what has been the result of breaking up the periodical collection and placing the specialized journals with the rest of the subject literature for each field? In general, readers find that this plan saves them time, because of the ease with which they can go from the books to the journals. A few people, however, miss the general periodical room when they read current issues in several fields. Unless the fields are related, such readers have to go to two or three rooms.

Three other questions will be discussed at a later time: ( I) the advantages and disadvantages of the Science-Divisional Reading Room versus separate departmental libraries; (2) the effect of this plan on the work of the general reference librarian; (3) the advantages and disadvantages of a separate documents librarian.

Summary: this discussion has attempted to describe the divisional-library program of the University of Colorado Library with a tentative and partial evaluation of some aspects of the program. Further aspects will be discussed in the future. 